\title{
Global Perspective of Speech Pathology Education
}

\author{
Li-Rong Lilly Cheng \\ San Diego State University, San Diego, Calif., USA
}

Excellence is a habit, not an act. Aristotle

Tell me and I will forget, show me and I may not remember, involve me and I will understand. Native American Philosopher

The entire world population is over 3.4 billion, with more than half of the world's population living in areas where a single hazard could significantly impact them. An example of the connectedness of the global conditions is the recent catastrophe that the tsunamis brought to southeast Asia, south Asia and Africa. It is imperative that we understand the world that we share and the challenges that we face. Over one third of the world's urban population lives in a slum and it is projected that in 30 years that figure will be have doubled to 2 billion. The world population is continually increasing, by 2050 the world population is expected to reach 9.1 billion. The world population will age rapidly over the next 45 years.

This global population is spread across seven continents with people speaking over 6,700 languages and over 399,000 languages and dialects. Some are spoken by over a billion people and others are shared only by a few. The development of speech pathology education differs from area to area and from region to region. What is being taught in Iceland may not be included in Honduras, what is being prepared in Brazil may be unheard of in Bermuda. Countries such as Iraq are barely capable of providing basic needs while countries such as Sweden provide health coverage for her entire populace. Islands may be isolated from the larger continents, but some islands are progressing rapidly such as Malta and other islands such as Sumatra are not making many changes. Countries such as Burma (Myanmar) are still going through political unrest and very little information is available about the current status while countries such as the United States are going on-line. These disparities and differences are continuing to challenge the education committee of the International Association of Lopopedics and Phoniatrics (IALP).

In addition, the entire world is progressing rapidly in technology and information. The services we provide continue to expand. The mission of the IALP is to work

\begin{tabular}{ll}
\hline KARGER & ( 2006 S. Karger AG, Basel \\
Fax +41 61 306 12 34 & 1021-7762/06/0581-0005\$23.50/0 \\
$\begin{array}{l}\text { E-Mail karger@karger.ch } \\
\text { www.karger.com }\end{array}$ & $\begin{array}{l}\text { Accessible online at: } \\
\text { www.karger.com/fpl }\end{array}$
\end{tabular}

Li-Rong Lilly Cheng, PhD

San Diego State University

Dean's Office, Hepner Hall 124 CHHS

San Diego, CA 92182 (USA), Tel. +1 7607508300

Fax +1 760750 3004, E-Mail lcheng@mail.sdsu.edu 
for the benefit of persons with speech, language, voice, swallowing and hearing disorders. In order to accomplish the goals and objectives of IALP, a closer examination of the education of speech-language pathologists (SLPs) is necessary.

This special issue is devoted to the education of SLPs from global perspectives. Many members of the education committee provided articles detailing the current status of their region or country. Other educators and experts have provided information on graduate education. All in all, the purpose of this special issue is to share current information about education from multiple perspectives.

The United States of America has the largest number of education programs and there are countries and areas where there is no program. In this issue, we start out with Dolores Battle's article on the education of SLPs in the United States followed by Jeri Logemann's article on the preparation of SLPs in the United States at the master's level. Tanya Gallagher's article follows the continuum and is focused on doctoral education in the United States emphasizing the critical shortages and plans for reshaping the future. In the Americas, there is a great gap in economic development between countries. Our next article from Mara Behlau and Gisele Gasparini details the challenges of providing education in speech-language pathology and audiology in Brazil.

Ewa Söderpalm provides an article on the Scandinavian experience. Margaret Leahy, Dodd, Walsh and Murphy share an article on education for practice in the UK and Ireland based on their work on implementing problem-based learning. Helen Grech provides an update on the education in logopedics in the Maltese Islands.

Alison Ferguson discusses the influences of competency-based occupation standards on Australian speech pathology education. Kyoko Iitaka presents issues of Japanese speech therapy education based on the 1995 IALP Guidelines.

We have only sampled a few areas in the world for this issue and understand the needs to provide comprehensive information about the current education status of the future generation of SLPs. We hope to cover many more areas in our future research and documentation.

Li-Rong Lilly Cheng, San Diego, Calif., USA 